\title{
Purification and Characterization of Ascorbic Acid Phosphorylating Enzyme from Pseudomonas azotocolligans
}

\author{
Satoshi Korzumi, Akihiko Maruyama and Tatsuro FujIo* \\ Tokyo Research Laboratories, Kyowa Hakko Kogyo Co., Ltd., \\ 3-6-6 Asahimachi, Machida-shi, Tokyo 194, Japan \\ Received June 18, 1990
}

\begin{abstract}
A enzyme that catalyzed the specific formation of ascorbic acid-2-phosphate (AsA2P) from ascorbic acid (AsA) and adenosine-5' -triphosphate (ATP), was purified 3,200-fold to homogeneity from a cell extract of Pseudomonas azotocolligans. The purified enzyme appeared as a single band on sodium dodecyl sulfate-polyacrylamide gel electrophoresis, and consisted of a single polypeptide with a molecular weight of about 30,000 . Of phosphoryl donors tested, $p$-nitrophenylphosphate ( $p$-NPP) and pyrophosphate (PPi) were as effective as ATP. Optimal pHs for the phosphorylating activity were around 4.0 and 5.5 when PPi and ATP were used as phosphoryl donors, respectively. The $K m$ for AsA was $147 \mathrm{~mm}$. The enzyme activity was inhibited by $\mathrm{Cu}^{2+}$, but not by sulfhydryl reagents.

The enzyme simultaneously had phosphatase activity at weakly acidic or neutral $\mathrm{pH}$ and the $\mathbf{K m}$ for $p$-NPP in the phosphatase activity was $0.38 \mathrm{~mm}$. The enzyme was tentatively named "ascorbic acid phosphorylating enzyme."
\end{abstract}

Ascorbic acid (AsA) is widely used, for example, in medicines, foodstuffs, and cosmetics, but has the disadvantage that it is susceptible to thermal and oxidative degradation. Modifications of AsA to a more stable form have been reported from a number of laboratories. ${ }^{1-6)}$ Among them were ascorbic acid-2-phosphate (AsA2P), ${ }^{7)}$ ascorbic acid-2sulfate, and ascorbic acid $\alpha$-glucoside. ${ }^{8)} \mathrm{AsA} 2 \mathrm{P}$ shows very high stability in vitro, and is easily converted to AsA in vivo by enzymatic dephosphorylation (Fig. 1). AsA2P has been shown to promote fibloblast growth and have

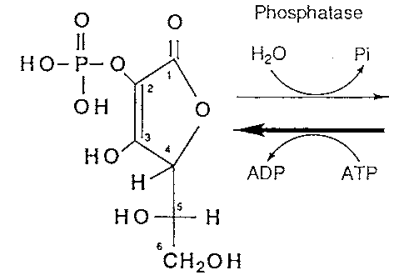

AsA2P

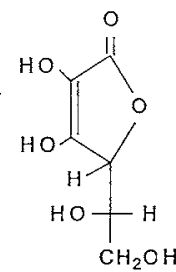

AsA
Fig. 1. The Structure of AsA and AsA2P. an antiscorbutic activity like AsA. ${ }^{9)}$

In our previous paper, ${ }^{10)}$ we described the existence of the enzyme activity in Pseudomonas azotocolligans KY4661 that catalyzed the specific formation of AsA2P from AsA and ATP, a novel reaction not previously reported.

Here we report the purification and characterization of the enzyme named "ascorbic acid phosphorylating enzyme (APE)" from $P$. azotocolligans KY4661.

\section{Materials and Methods}

Chemicals. Ascorbic acid-2-phosphate (AsA2P) was purchased from Wako Pure Chemical Industries, Ltd., Osaka, Japan. The standard marker proteins for sodium dodecyl sulfate-polyacrylamide gel electrophoresis (SDSPAGE) and high performance liquid chromatography (HPLC) were from Bio-Rad Laboratories and Pharmacia LKB Biotechnology Inc, respectively. All other chemicals used were commercially available and of analytical grade.

Microorganism and growth conditions. P. azotocolligans KY4661 was from type cultures preserved in our

* Present adress: Technical Research Laboratories, Kyowa Hakko Kogyo Co., Ltd., 1-1 Kyowamachi, Hofu-shi, Yamaguchi 747 , Japan. 
laboratory. Cells were grown in a test tube containing $10 \mathrm{ml}$ of nutrient medium composed of $1 \%$ glucose, $1 \%$ polypeptone, $0.7 \%$ meat extract, $0.5 \%$ yeast extract, and $0.3 \% \mathrm{NaCl}(\mathrm{pH} \mathrm{7.2})$, with reciprocal shaking at $28^{\circ} \mathrm{C}$ for $24 \mathrm{hr}$. The cells were transferred into a 2 -liter shaking flask containing $140 \mathrm{ml}$ of the same medium and grown at $28^{\circ} \mathrm{C}$ for $24 \mathrm{hr}$ with rotary shaking. The resultant subculture was inoculated into a 5-1 jar fermentor (type $\mathrm{KMJ}-5-6$; Mitsuwa Co., Japan) containing 2.51 of the same fresh medium. Cultivation was done at $28^{\circ} \mathrm{C}$ for $24 \mathrm{hr}$ with aeration (1 1 per liter of medium per min) and agitation ( $600 \mathrm{rpm})$. The grown cells were harvested by centrifugation at $4^{\circ} \mathrm{C}$.

Assay for AsA2P formation. The standard reaction mixture $(1.0 \mathrm{ml})$ consisted of $40 \mathrm{~mm}$ potassium phosphate buffer (PKB) (pH 5.5), $200 \mathrm{~mm} \mathrm{AsA}, 40 \mathrm{~mm} \mathrm{ATP,} 10 \mathrm{~mm}$ $\mathrm{MgSO}_{4} \cdot 7 \mathrm{H}_{2} \mathrm{O}$, and enzyme. The reaction was done at $30^{\circ} \mathrm{C}$ for $150 \mathrm{~min}$, and the AsA2P formed was measured by HPLC. One unit of APE activity was defined as the amount of enzyme that produced $1 \mu \mathrm{mol}$ of AsA2P per min.

Phosphatase assay. The reaction mixture contained $0.1 \mathrm{M}$ different kinds of buffers, enzyme, and $5 \mathrm{~mm} p$-NPP or $62 \mathrm{~mm}$ AsA2P. The $p$-nitrophenol $(p$-NP) formed was measured at $400 \mathrm{~nm}$ under alkaline conditions then calculated from the standard curve obtained from authentic $p$-NP. AsA formed was measured by HPLC.

Analysis. AsA and AsA2P was measured by HPLC as described previously. ${ }^{10}$ Protein was measured by a Bio-Rad protein assay kit with $y$-globulin as the standard.

Purification of APE from $P$. azotocolligans. All purification procedures were done at 0 to $4^{\circ} \mathrm{C}$.

Step 1. Preparation of cell extracts. Cells $(570 \mathrm{~g}$, wet weight) were suspended in 5.71 of $0.01 \mathrm{M} \mathrm{PKB} \mathrm{(pH} \mathrm{7.0)}$ and then disrupted with a Manton-Gaulin Laboratory Homogenizer (Manton-Gaulin Manufacturing Co., Inc., U.S.A.). The cell debris was removed by centrifugation $(10,000 \times g$ for $30 \mathrm{~min})$.

Step 2. Ammonium sulfate fractionation. The cell extracts were fractionated by salting out with solid ammonium sulfate to 30 to $50 \%$ saturation. The precipitate formed was collected by centrifugation at $10,000 \times g$ for $30 \mathrm{~min}$, dissolved in 11 of $0.01 \mathrm{M}$ PKB ( $\mathrm{pH} \mathrm{7.0)}$ ), and then dialyzed against the same buffer.

Step 3. CM-Sepharose column chromatography. The dialyzed fraction was adjusted to $\mathrm{pH} 6.0$ with phosphoric acid, and then put on a CM-Sepharose column $(7.4 \times$ $19 \mathrm{~cm}$ ), previously equilibrated with $0.02 \mathrm{M}$ PKB $(\mathrm{pH} 6.0)$. After washing the column with the same buffer, the enzyme was eluted with a linear gradient of 0 to $0.25 \mathrm{M}$ $\mathrm{NaCl}$ in the buffer. Active fractions were combined and concentrated to $44 \mathrm{ml}$ with an Amicon YM 10 membrane.

Step 4. Chromatofocusing. The concentrated enzyme fraction was put on a Sephadex G-25 column $(2.2 \times 39 \mathrm{~cm})$, previously equilibrated with $0.025 \mathrm{M}$ triethylamine $-\mathrm{HCl}$
(pH 11.0). Protein was desalted by elution with $0.025 \mathrm{M}$ triethylamine- $\mathrm{HCl}(\mathrm{pH} 11.0)$. The void peak containing material absorbing at $A_{280}$ was pooled and concentrated to $28 \mathrm{ml}$ with an Amicon YM10 membrane. The desalted protein was put on a PBE118 column $(1.4 \times 55 \mathrm{~cm})$ equilibrated with $0.025 \mathrm{M}$ triethylamine- $\mathrm{HCl}(\mathrm{pH} 11.0)$. Enzyme was eluted with Pharmalyte $\mathrm{pH} 8-10.5-\mathrm{HCl}(\mathrm{pH}$ 7.5). The active fractions were pooled and concentrated as before.

Step 5. Sephadex G-75 chromatography. The concentrated protein fraction was put on a Sephadex G-75 column $(2.3 \times 80 \mathrm{~cm})$, previously equilibrated with $0.02 \mathrm{M}$ PKB ( $\mathrm{pH} 7.0)$. The protein was eluted with the same buffer and the active fractions were pooled, concentrated as before, and stored at $0^{\circ} \mathrm{C}$ until use.

Amino acid analysis. A sample of APE (1.2 mg) was hydrolyzed in $6 \mathrm{~N} \mathrm{HCl}$ and the amino acid was analyzed with a JOEL JLC-300 amino acid analyzer.

Measurement of molecular weight. Estimation of the molecular weight of the enzyme by gel filtration was done on a Shim-pack DIOL-150 column $(7.9 \mathrm{~mm} \times 50 \mathrm{~cm}$, Shimadzu Seisakusho, Tokyo, Japan) eluted with $0.1 \mathrm{M}$ potassium phosphate buffer containing $0.2 \mathrm{M} \mathrm{NaCl}$ at a flow rate of $1.0 \mathrm{ml}$ per min.

Polyacrylamide gel electrophoresis. Polyacrylamide gel electrophoresis in the presence of sodium dodecyl sulfate (SDS) was done by the method of Laemmli. ${ }^{11)}$ Proteins were stained with Coomassie brilliant blue R-250.

\section{Results}

\section{Purification of $A P E$}

A typical purification procedure of $P$. azotocolligans APE is summarized in Table $\mathrm{I}$. The enzyme was purified approximately 3,200 -fold from the cell extract with a yield of $16 \%$. The preparation at the final step of purification had a single band on SDS-PAGE (Fig. 2).

\section{Molecular weight}

The molecular weight of the enzyme was estimated to be about 31,500 by gel filtration, and 29,000 by SDS-PAGE (Fig. 2). Thus, the enzyme appears to be a monomeric structure.

\section{Amino acid composition}

The amino acid composition of the purified enzyme is given in Table II. The number of phenylalanine residues per mole could not be 
Table 1. Purification of APE from $P$. azotocolligans

\begin{tabular}{lccccr}
\hline Step & $\begin{array}{c}\text { Protein } \\
(\mathrm{mg})\end{array}$ & $\begin{array}{c}\text { Total activity } \\
\left(\mathrm{U}^{a}\right)\end{array}$ & $\begin{array}{c}\text { Specific activity } \\
(\mathrm{U} / \mathrm{mg})\end{array}$ & $\begin{array}{c}\text { Yield } \\
(\%)\end{array}$ & $\begin{array}{c}\text { Purification } \\
(- \text { fold })\end{array}$ \\
\hline Cell extract & 102,620 & 210 & 0.002 & 100 & 1 \\
Ammonium sulfate & 25,534 & 190 & 0.008 & 91 & 4 \\
CM-Sepharose & 977 & 170 & 0.173 & 81 & 85 \\
Chromatofocusing & 12.7 & 38 & 2.90 & 18 & 1417 \\
Sephadex G-75 & 5.1 & 33 & 6.39 & 16 & 3196 \\
\hline
\end{tabular}

a $\quad \mathrm{IU}=1 \mu \mathrm{mol}$ AsA2P per min.

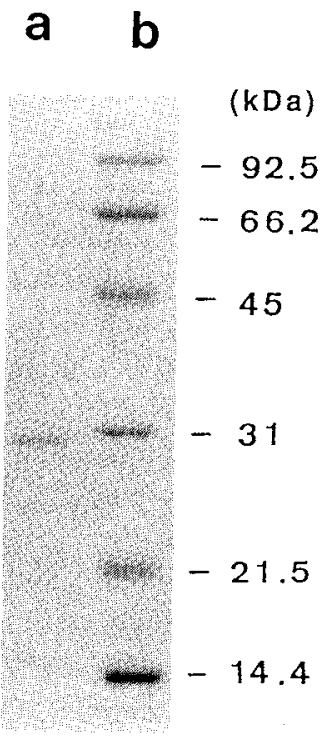

Fig. 2. Molecular Weight Measurement.

The purified enzyme was treated with SDS in the presence of 2-mercaptoethanol and electrophoresed on a $0.1 \%$ SDS $-12.5 \%$ polyacrylamide gel. Lane a, APE; $b$, molecular weight markers: phosphorylase $B\left(M_{r} 92,500\right)$; bovine serum albumin $\left(M_{r} 66,200\right)$; ovalbumin $\left(M_{r} 45,000\right)$; carbonic anhydrase $\left(M_{r} 31,000\right)$; soybean trypsin inhibitor $\left(M_{r} 21,500\right)$; lysozyme $\left(M_{r}, 14,400\right)$.

accurately measured because of the low contents in the protein.

\section{Substrate specificity}

The activity of the enzyme to form AsA2P from AsA and various phosphoryl donors are given in Table III. Besides ATP, acetylphosphate, $p$-NPP, PPi, tripolyphosphate, and tetrapolyphosphate were also found to be used as phosphoryl donors, but phosphoric acid was inert. The apparent $K m$ for ATP and PPi were
Table II. AMINo ACID COMPOSITION OF APE

\begin{tabular}{lcc}
\hline Amino acid & Mol\% & Residues $/ \mathrm{mol}^{a}$ \\
\hline Asx & 8.74 & 22 \\
Thr & 5.94 & 15 \\
Ser & 4.95 & 13 \\
Glx & 8.24 & 21 \\
Pro & 8.41 & 22 \\
Gly & 8.41 & 22 \\
Ala & 20.94 & 54 \\
Val & 4.12 & 11 \\
Met & 2.64 & 7 \\
Ile & 1.56 & 4 \\
Leu & 7.17 & 18 \\
Tyr & 2.89 & 7 \\
Phe & N.D. & N.D. \\
Lys & 2.72 & 7 \\
His & 3.22 & 8 \\
Arg & 9.32 & 24 \\
Trp & 0.66 & 2 \\
Cys & - & - \\
\hline
\end{tabular}

N.D. = not detected.

a Nearest integral number calculated on the basis of the molecular weight of 31,500 estimated by Shim-pack DIOL-150 gel filtration.

$b$ Not determined.

Table III. Phosphoryl Donor Specificity of APE

\begin{tabular}{lcc}
\hline Substrate & $\mathrm{pH}$ & Relative activity \\
\hline ATP & 5.6 & 100 \\
ATP & 4.3 & 22 \\
Acetylphosphate & 4.1 & 145 \\
-NPP & 4.1 & 111 \\
Pyrophosphate & 4.1 & 114 \\
Tripolyphosphate & 4.1 & 83 \\
Tetrapolyphosphate & 4.1 & 76 \\
Phosphoric acid & 4.1 & 0 \\
\hline
\end{tabular}

calculated to be $24 \mathrm{~mm}$ and $10 \mathrm{~mm}$, respectively. Isoascorbic acid, a stereoisomer of L-ascorbic acid, was also phosphorylated by the purified 


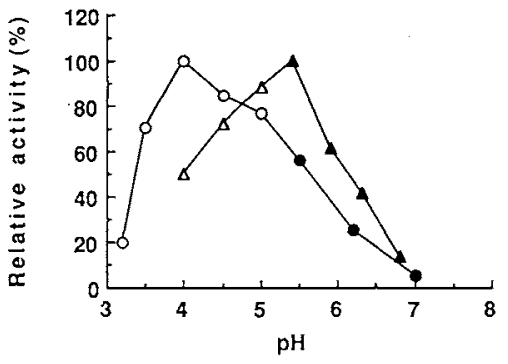

Fig. 3. Effects of $\mathrm{pH}$ of APE Activity.

The activity of the enzyme was measured in the standard assay conditions described in Materials and Methods, except for buffer. The buffers used were $(O, \triangle)$ sodium acetate buffer and $(\boldsymbol{O}, \boldsymbol{\Delta})$ potassium phosphate buffer. The substrate were $(\triangle, \boldsymbol{\Delta})$ ATP and $(O, \bullet)$ PPi. The activity at $\mathrm{pH} 5.5$ for $\mathrm{ATP}$ and at 4.0 for $\mathrm{PPi}$ was taken as $100 \%$.

Table IV. EfFects of Various Chemicals ON APE ACTIVITY

The reaction mixture contained $40 \mathrm{~mm}$ acetate buffer, $200 \mathrm{~mm}$ AsA, $100 \mathrm{~mm} \mathrm{PPi}$, and enzyme. The enzyme was incubated with a compound for $10 \mathrm{~min}$ before the reaction was started with AsA and PPi.

\begin{tabular}{lcc}
\multicolumn{1}{c}{$\begin{array}{c}\text { Compound } \\
\text { added }\end{array}$} & $\begin{array}{c}\text { Concentration } \\
(\mathrm{mM})\end{array}$ & $\begin{array}{c}\text { Relative } \\
\text { activity }\end{array}$ \\
\hline $\mathrm{None}$ & - & 100 \\
$\mathrm{Ca}^{2+}$ & 1.0 & 109 \\
$\mathrm{Mg}^{2+}$ & 1.0 & 76 \\
$\mathrm{Mg}^{2+}$ & 10.0 & 121 \\
$\mathrm{Fe}^{2+}$ & 1.0 & 121 \\
$\mathrm{Mn}^{2+}$ & 1.0 & 112 \\
$\mathrm{Cu}^{2+}$ & 1.0 & 64 \\
$\mathrm{Cu}^{2+}$ & 10.0 & 32 \\
$\mathrm{NaF}$ & 10.0 & 112 \\
EDTA & 10.0 & 112 \\
NaN & 1.0 & 87 \\
$\alpha, \alpha^{\prime}$-Dipyridyl & 1.0 & 86 \\
8-Hydroxyquinoline & 1.0 & 93 \\
$p$-Hydroxymercuribenzoate & 5.0 & 112 \\
5,5'-Dithiobis(2-benzoate) & 5.0 & 97 \\
Iodoacetamide & 1.0 & 111 \\
\hline
\end{tabular}

APE (data not shown). The $K m$ for AsA was calculated to be $147 \mathrm{~mm}$.

\section{Effects of $p H$ and temperature}

The purified enzyme was active between $\mathrm{pH}$ 3 and 8 . The maximum activity was obtained at $\mathrm{pH} 5.5$ when ATP was used as the substrate, but it shifted to around $\mathrm{pH} 4.0$ when PPi was used (Fig. 3). The optimal temperature was

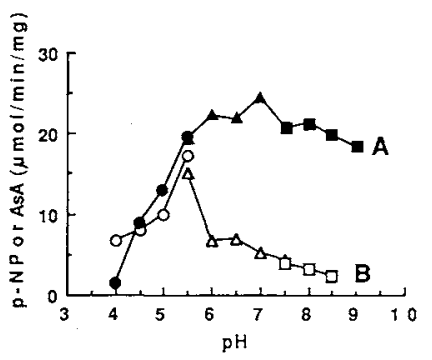

Fig. 4. Effects of $\mathrm{pH}$ on Phosphatase activity.

The phosphatase activity was measured as described in Materials and Methods. The buffer used were $(O$, sodium acetate buffer, $(\triangle, \boldsymbol{\Delta})$ Tris maleate buffer, and $(\square, \square)$ Tris hydrochloride buffer. The substrate were $p$-NPP (A) and AsA2P (B).

$50^{\circ} \mathrm{C}$. When the enzyme was incubated for $30 \mathrm{~min}$ at various temperatures in $10 \mathrm{~mm}$ potassium phosphate buffer $(\mathrm{pH} 7.0)$, the original activity was retained at $50^{\circ} \mathrm{C}$, but decreased to $67 \%$ and $0 \%$ at $60^{\circ} \mathrm{C}$ and $70^{\circ} \mathrm{C}$, respectively. Purified APE was stable for several weeks when stored at $4^{\circ} \mathrm{C}$ in $10 \mathrm{~mm} \mathrm{PKB}$ ( $\mathrm{pH} 7.0)$ (data not shown).

\section{Inhibitors}

The effects of various agents on the enzyme activity are shown in Table IV. Among the divalent metal ions examined, $\mathrm{Cu}^{2+}$ inhibited the enzyme activity, but other divalent metal cations such as $\mathrm{Ca}^{2+}, \mathrm{Mg}^{2+}, \mathrm{Fe}^{2+}, \mathrm{Mn}^{2+} \mathrm{did}$ not have any significant effects on the enzyme activity. The enzyme activity was not inhibited by sulfhydryl reagents, suggesting that APE contained no active-site thiol.

\section{Phosphatase activity}

The phosphatase activity with $p$-NPP or AsA2P as a substrate was detected at weakly acidic or neutral pH (Fig. 4). The $K m$ for $p$-NPP and $\mathrm{AsA} 2 \mathrm{P}$ at $\mathrm{pH} 7.0$ were $0.38 \mathrm{~mm}$ and $5.4 \mathrm{mM}$, respectively.

\section{Discussion}

We have found the phosphorylating activities of AsA in three bacteria including $P$. azotocolligans $\mathrm{KY} 4661$, as reported in our previous paper. ${ }^{10)}$ At that time, ATP was used 
as a phosphoryl donor for the phosphorylation of AsA with either permealized cells or cell extracts, because it was thought to be catalyzed by a sort of kinase. The purified APE, however, used a veriety of phosphoryl compounds as the donor besides ATP (Table III), indicating that it must be a phosphatase or phosphotransferase. In fact Tani et al. reported that the crystalline acid phosphatase of Escherichia freundii could catalyze the phosphorylation of pyridoxine. ${ }^{12)}$ Phosphorylation of sugars, ${ }^{13}$ ) nucleosides, ${ }^{14,15)}$ and vitamins ${ }^{16,17)}$ were also reported to be catalyzed by phosphatase or phosphotransferase in several laboratories.

Therefore, we have studied the phosphatase activity of the purified APE. The $K m$ for $p$-NPP and AsA2P in the phosphatase activity were $0.38 \mathrm{~mm}$ and $5.4 \mathrm{~mm}$, respectively, which were much lower than that for AsA, $147 \mathrm{~mm}$ in the phosphorylating reaction. The optimal $\mathrm{pH}$ for the AsA phosphorylation by APE was around 4.0 and 5.5 with PPi and ATP, respectively. Phosphatase of $E$. freundii, ${ }^{12)}$ and $P$. mirabilis ${ }^{17)}$ were reported to show the phosphorylating activities in a similar acidic range of $\mathrm{pH}$.

Combined with these results, the conversion of AsA to AsA2P by APE might be done by the reversed reaction of its phosphatase activity. This is supported by the results that less than $50 \%$ of AsA could be phosphorylated even under the optimized conditions (data not shown).

Recently, Tani et al. ${ }^{18,19)}$ reported an enzyme activity in Citrobacter freundii that phosphorylated AsA mainly at the C-6 position. Our enzyme is different from theirs in that it could phosphorylate at the C-2 position specifically. To achieve more efficient production of AsA2P from AsA, the attempt is being undertaken to clone the gene encoding this enzyme.

Acknowledgment. We thank S. Teshiba for helpful suggestions in preparation of this manuscript; $T$. Iida for the amino acid analysis.

\section{References}

1) H. Nomura and K. Sugimoto, Japan Tokkyo Koho, 69, 218 (Jan. 8, 1969).

2) H. Tanaka and R. Yamamoto, Yakugaku Zasshi, 86, 376 (1966).

3) R. O. Mumma, Biochim. Biophys. Acta, 165, 571 (1968).

4) C. G. Mead and F. J. Finamore, Biochemistry, 8, 2652 (1968).

5) H. Nomura and K. Sugimoto, Chem. Pharm. Bull., 14, 1039 (1966).

6) H. Nomura, M. Shimomura and S. Sugimoto, Chem. Pharm. Bull., 19, 1433 (1971).

7) H. Miwa, H. Nomura, Y. Imai and H. Takashima, Vitamins, 41, 387 (1970).

8) N. Muto, T. Nakamura and I. Yamamoto, $J$. Biochem., 107, 222 (1990).

9) R. Hata, Seikagaku, 60, 201 (1988).

10) A. Maruyama, S. Koizumi and T. Fujio, Agric. Biol. Chem., 54, 2309 (1990).

11) U. K. Laemmli, Nature, 227, 680 (1970).

12) Y. Tani, T. Tochikura, H. Yamada and K. Ogata, Biochem. Biophys. Res. Commun., 28, 769 (1967).

13) R. K. Morton, Biochem. J., 70, 134 (1958).

14) K. Ogata, Y. Tani, S. Yamamoto and T. Tochikura, Agric. Biol. Chem., 28, 809 (1964).

15) G. Brawerman and E. Chargaff, Biochim. Biophys. Acta, 16, 524 (1955).

16) S. A. Kumar and C. S. Vaidyanathan, Biochim. Biophys. Acta, 73, 98 (1963).

17) M. Kuwahara, T. Tachiki, T. Tochikura and K. Ogata, Agric. Biol. Chem., 36, 745 (1972).

18) Y. Tani and T. Hattori, Abstracts of Papers, the Annual Meeting of the Japan Society for Bioscience, Biotechnology, and Agrochemistry, Tokyo, April, 1987, p. 696.

19) Y. Tani and T. Hattori, Japan Kokai Tokkyo Koho, $88,214,190$ (Sep. 6, 1988). 